\title{
Viral Load Before and After Exchange Transfusion in a Neonate with Hyperbilirubinemia and Congenital Cytomegalovirus Infection
}

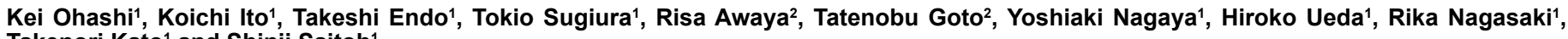
Takenori Kato ${ }^{1}$ and Shinji Saitoh ${ }^{1}$

${ }^{1}$ Department of Pediatrics and Neonatology, Graduate School of Medical Sciences, Nagoya City University, Nagoya, Japan

${ }^{2}$ Department of Pediatrics, Holy Spirit Hospital, Nagoya, Japan

\begin{abstract}
Introduction: Cytomegalovirus is the most common cause of intrauterine infection in developed countries. Between $10 \%$ and $15 \%$ of infants infected with congenital cytomegalovirus exhibits the clinically apparent or symptomatic form of the disease. Exchange transfusion is an established therapy for hyperbilirubinemia and severe anemia. However, to the best of our knowledge, the viral load of cytomegalovirus before and after exchange transfusion has not been previously reported.

Case report: A Japanese female was delivered at 36 weeks of gestation to a 29 -year-old gravida 3 para 3 by emergency Cesarean section because of non-reassuring fetal status. Hepatomegaly, splenomegaly, generalized petechiae, leptocephaly, and jaundice were noted at birth. On admission, her total bilirubin was $14.2 \mathrm{mg} / \mathrm{dL}$, cytomegalovirus immunoglobulin $\mathrm{M}$ was positive $(4.63 \mathrm{mg} / \mathrm{dL})$, and her head ultrasound and computed tomography showed left intraventricular calcification and bilateral ventriculomegaly. Toxoplasma, rubella, and herpes simplex virus serologies were negative. The exchange transfusion was performed for the treatment of early onset hyperbilirubinemia, not for the treatment of congenital cytomegalovirus infection. The cytomegalovirus viral load before and after exchange transfusion was investigated by real-time polymerase chain reaction, and the plasma viral load of cytomegalovirus was not significantly decreased from before $\left(8.7 \times 10^{5} / \mathrm{mL}\right)$ to after $\left(4.3 \times 10^{5} / \mathrm{mL}\right)$ exchange transfusion.
\end{abstract}

Conclusion: Exchange transfusion did not reduce the viral load of cytomegalovirus in severe congenital cytomegalovirus infection.

Keywords: Congenital cytomegalovirus infection; Exchange transfusion; Hyperbilirubinemia; Real-time polymerase chain reaction

Abbreviations: CMV: Cytomegalovirus; RBC: Red Blood Cell; PCR: Polymerase Chain Reaction; NICU: Neonatal Intensive Care Unit; MRI: Magnetic Resonance Imaging

\section{Introduction}

Cytomegalovirus (CMV) is the most common cause of intrauterine infection in developed countries. In our previous study, the prevalence of congenital CMV infection was found to be $0.2 \%$ in Japan [1]. Between $10 \%$ and $15 \%$ of infants infected with congenital CMV exhibits the clinically apparent or symptomatic form of the disease.

Exchange transfusion is an established therapy for hyperbilirubinemia [2] and severe anemia [3]. But it is not a common treatment for viremia, and to the best of our knowledge, the viral load of CMV before and after exchange transfusion has not been previously reported. Therefore, to study the effect of exchange transfusion on viral load in a neonate with severe congenital CMV infection and hyperbilirubinemia, the plasma viral load of CMV was measured both before and after exchange transfusion by real-time polymerase chain reaction (PCR).

\section{Case Report}

A female infant was delivered at 36 weeks of gestation to a 29 -yearold Japanese by emergency Cesarean section due to non-reassuring fetal status. The patient's measurements at birth were as follows: weight, $1792 \mathrm{~g}$ (third percentile); length, $43.5 \mathrm{~cm}$ (<tenth percentile); and head circumference, $29.6 \mathrm{~cm}$ (tenth percentile). The mother's CMV immunoglobulins $\mathrm{M}$ and $\mathrm{G}$ were positive $(7.43 \mathrm{mg} / \mathrm{dL}$ and 27.4 $\mathrm{mg} / \mathrm{dL}$, respectively). The patient's Apgar score was 1 at 1 minute and 4 at 5 minutes. Hepatomegaly, splenomegaly, generalized petechiae, leptocephaly and jaundice were noted at birth.
On admission, her white blood cell count was $30,300 / \mu \mathrm{L}$, hemoglobin was $11.9 \mathrm{~g} / \mathrm{dL}$, platelet count was $16,000 / \mu \mathrm{L}$, total bilirubin was $14.2 \mathrm{mg} / \mathrm{dL}$, direct bilirubin was $9.3 \mathrm{mg} / \mathrm{dl}$, aspartate aminotransferase was $471 \mathrm{IU} / \mathrm{L}$, alanine aminotransferase was 105 IU/L, lactate dehydrogenase was $2965 \mathrm{IU} / \mathrm{L}$, and carbon monoxide hemoglobin was $0.2 \%$. Her blood type was type B D (+), and her maternal blood type was B D (+). Her head ultrasound and computed tomography revealed left intraventricular calcification and bilateral ventriculomegaly. Her abdominal ultrasound revealed hepatomegaly and splenomegaly. Toxoplasma, rubella, and herpes simplex virus serologies were negative, and CMV immunoglobulin $\mathrm{M}$ was positive $(4.63 \mathrm{mg} / \mathrm{dL})$ in her blood. On day 0 , exchange transfusion was performed for hyperbilirubinemia, not for the treatment of congenital cytomegalovirus infection. After exchange transfusion, total bilirubin was decreased to $7.5 \mathrm{mg} / \mathrm{dL}$ and phototherapy was continued. She was then transferred to tertiary-referral NICU on day 2 of life for antiviral therapy. Ganciclovir at a dosage of $12 \mathrm{mg} / \mathrm{kg} /$ day from day 1 to day 49 and valganciclovir at a dosage of $32 \mathrm{mg} / \mathrm{kg} / \mathrm{day}$ from day 50 were used.

The patient was discharged at 2 months. She had no chorioretinitis,

*Corresponding author: Tokio Sugiura, Department of Pediatrics and Neonatology, Graduate School of Medical Sciences, Nagoya City University, 1 Kawasumi, Mizuho-Cho, Mizuho-Ku, Nagoya 467-8601, Japan, Tel: +8152853 8246; Fax: +81 52842 3449; E-mail: tokio@med.nagoya-cu.ac.jp

Received February 04, 2014; Accepted February 25, 2014; Published February 27, 2014

Citation: Ohashi K, Ito K, Endo T,Sugiura T, Awaya R, et al. (2014) Viral Load Before and After Exchange Transfusion in a Neonate with Hyperbilirubinemia and Congenital Cytomegalovirus Infection. J Clin Case Rep 4: 343. doi:10.4172/21657920.1000343

Copyright: (C) 2014 Ohashi K, et al. This is an open-access article distributed under the terms of the Creative Commons Attribution License, which permits unrestricted use, distribution, and reproduction in any medium, provided the original author and source are credited. 
and her auto auditory brainstem-evoked response was normal. On head magnetic resonance imaging (MRI) examination on day 42 , the signs of kernicterus were not detected. Written informed consent for both the studies and the reporting of this case was obtained from all parents.

For exchange transfusion, red blood cells (RBCs), fresh frozen plasma, and platelets were given using 2 separate catheters (continuous technique). The total blood volume of exchange transfusion was $163 \mathrm{~mL} / \mathrm{kg}$. For quantification of CMV, real-time PCR for CMV amplification was performed as in our previous study [1]. CMV DNA was detected in phlebotomized plasma samples obtained both before and after exchange transfusion. Before exchange transfusion, the patient's plasma CMV DNA levels were markedly elevated at $8.7 \times 10^{5} /$ $\mathrm{mL}$ (Figure 1). After exchange transfusion, the CMV DNA level was not significantly decreased at $4.3 \times 10^{5} / \mathrm{mL}$. On days 0 and 1 , CMV DNA levels in urine were $3.3 \times 10^{8} / \mathrm{mL}$ and $3.3 \times 10^{9} / \mathrm{mL}$, respectively.

\section{Discussion}

In this study, the exchange transfusion was performed for the treatment of early onset hyperbilirubinemia. To the best of our knowledge, the viral load before and after exchange transfusion in a congenital CMV infection has not been previously reported. We investigated the viral loads of CMV both before and after exchange transfusion by real-time PCR as a result of the treatment and not for necessarily indicative of a reduction in CMV infection. In this case, the plasma viral load of CMV DNA was not significantly decreased from $8.7 \times 10^{5} / \mathrm{mL}$ before to $4.3 \times 10^{5} / \mathrm{mL}$ after exchange transfusion.

Exchange transfusion was started in the late 1940s both to decrease the mortality of hemolytic disease of the newborn and to prevent kernicterus in surviving patients [4,5]. Exchange transfusion was subsequently applied to neonatal hyperbilirubinemia from a variety of causes, and quickly became one of the most common neonatal procedures [6]. Exchange transfusion is recommended when total bilirubin is greater than $12 \mathrm{mg} / \mathrm{dL}$ in preterm infants born at less than 35 weeks of gestational age with risk factors such as asphyxia [7]. On day 0 , the present patient's total bilirubin was $14.2 \mathrm{mg} / \mathrm{dL}$; therefore, she was treated with exchange transfusion for hyperbilirubinemia.

A double blood volume exchange transfusion (160-180 mL/ $\mathrm{kg}$ ) is estimated to remove $90 \%$ of the initial RBCs and $50 \%$ of the available intravascular bilirubin [4]. In the present patient, the total

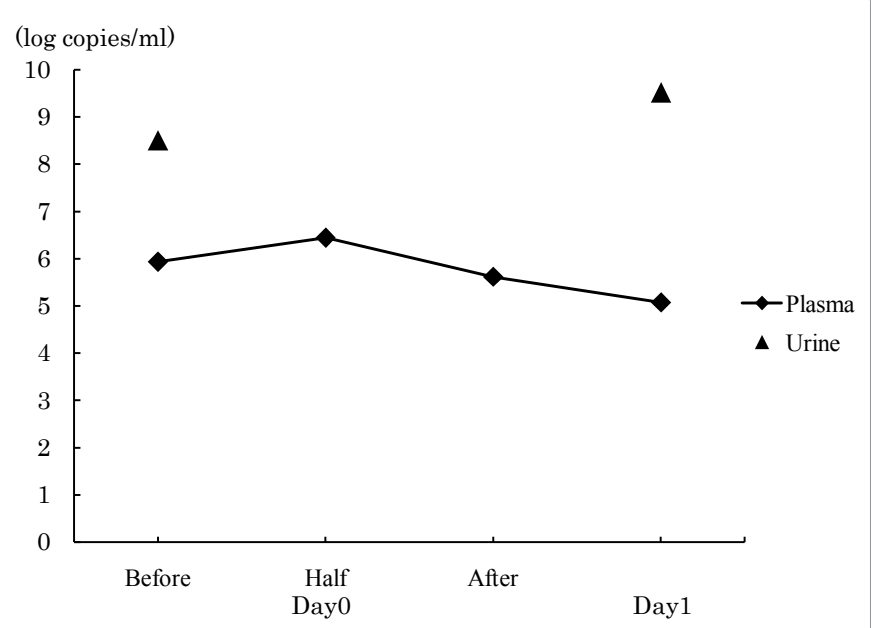

Figure 1: Viral load both before and after exchange transfusion on day 1. blood volume of exchange transfusion was $163 \mathrm{~mL} / \mathrm{kg}$, and the total bilirubin level was decreased from $14.2 \mathrm{mg} / \mathrm{dL}$ before to $7.5 \mathrm{mg} / \mathrm{dL}$ after exchange transfusion. Although exchange transfusion was effective for the hyperbilirubinemia, it did not significantly decrease the viral load of CMV. After a viral infection, during the phase of secondary viremia, different organ systems that have affinity for the virus are affected. CMV has affinity for many human organs, such as liver, spleen, brain, and others; however, its receptor has yet to be definitively identified. In the present case, constitutional symptoms were noted at birth and it seemed that the CMV invaded many organs, including the liver, spleen, and brain. Although $90 \%$ of the RBCs were removed by exchange transfusion, other organs might release CMV and the viral load of CMV was not significantly decreased after exchange transfusion.

The present study had several limitations. First, the viral load of CMV DNA in the blood products used at exchange transfusion was unable to be measured. However, even if CMV DNA had been detected in the blood products used at exchange transfusion, it would have had little effect on the result because the viral load showed almost no change between before and after exchange transfusion. In addition, the present study involved only one neonate with congenital CMV infection.

\section{Conclusion}

Exchange transfusion did not reduce the viral load of cytomegalovirus in severe congenital cytomegalovirus infection.

\section{References}

1. Endo T, Goto K, Ito K, Sugiura T, Terabe K, et al. (2009) Detection of congenita cytomegalovirus infection using umbilical cord blood samples in a screening survey. J Med Virol 81: 1773-1776.

2. Gibson BE, Todd A, Roberts I, Pamphilon D, Rodeck C, et al. (2004) Transfusion guidelines for neonates and older children. Br J Haematol 124: 433-453.

3. Sadana S, Mathur NB, Thakur A (1997) Exchange transfusion in septic neonates with sclerema: effect on immunoglobulin and complement levels. Indian Pediatr 34: 20-25.

4. Murray NA, Roberts IA (2004) Neonatal transfusion practice. Arch Dis Child Fetal Neonatal Ed 89: F101-107.

5. Louis KD, Fred HA Jr, William OT Jr (1951) Treatment with exchange transfusion. N Engl J Med 244: 39-49.

6. Steiner LA, Bizzarro MJ, Ehrenkranz RA, Gallagher PG (2007) A decline in the frequency of neonatal exchange transfusions and its effect on exchangerelated morbidity and mortality. Pediatrics 120: 27-32.

7. American Academy of Pediatrics Subcommittee on Hyperbilirubinemia (2004) Management of hyperbilirubinemia in the newborn infant 35 or more weeks of gestation. Pediatrics 114: 297-316. 